\title{
TRANSPLACENTAL TRANSMISSION OF HEPATITIS B VIRUS IN MAZANDARAN PROVINCE OF IRAN
}

\author{
Safieh Amini ${ }^{1}$, Saied Andalibi Mahmoodabadi ${ }^{1}$, Faramarz Taghavinejad ${ }^{1}$, Mahsa Joulaie ${ }^{1}$, Mahmoud \\ Mahmoodi Farahani ${ }^{2}$, and Soheila Hekmat ${ }^{*}$. \\ ${ }^{1}$ Dept. of Hepatitis and AIDS, Pasteur Institute of Iran, Tehran, Iran . \\ ${ }^{2}$ Dept. of Epidemiology \& Biostatistics, School of Public Health, Tehran Medical Sciences, Iran
}

\begin{abstract}
Mother to child transmission of Hepatitis B Virus is considered as the major route of HBV infection in newborns in Asia. But there is not enough data available on percentage of HBV transplacental transmission in Iran. 1219 pregnant women of Mazandaran province were screened for HBV markers (HBsAg, anti-HBc and anti-HBs). The infants born to HBV positive mothers were tested for the same markers by enzyme-linked immunosorbent assay. Presence of HBV-DNA in HBsAg and anti-HBc positive mothers and cord blood of their babies were also tested by PCR technique. HBsAg was detected in $2.6 \%$ of mothers, but only $20 \%(5 / 25)$ of neonates cord blood of carrier mothers were HBsAg positive. Hepatitis B-eAg was detected in $12 \%(3 / 25)$ of carriers mothers and in cord blood of their babies. HBV-DNA was detected in $12 \%(3 / 25)$ of carrier mothers but none of the babies' were positive for it. Meanwhile, HBV-DNA was detected in $6.5 \%(5 / 76)$ of HBsAg negative mothers who were anti-HBc positive. Despite presence of $2.6 \%$ carrier mothers in Mazandaran province, maternal transmission of HBV dose not seem to be the main route of infection.
\end{abstract}

Keywords: • transplacental $\bullet$ mother $\bullet$ cord blood $\bullet \mathrm{HBV} \bullet$ Iran

\section{Introduction}

$\mathrm{H}$ epatitis B is a major public health problem throughout the world. The People harboring this virus are at risk for developing chronic hepatitis, liver cirrhosis and primary hepatocellular carcinoma [1].

Asia is known as an endemic region for HBV infection. South East Asia and parts of Middle East with infection rate of $10-20 \%$ are considered the highly endemic areas for this infection $[2 ; 3]$. The high rate of $\mathrm{HBsAg}$ carriers in the Asian population is assumed to be due to sequential maternal neonate transmission [4]. The risk of HBV trans-mission from $\mathrm{HBeAg}$ or HBV DNA positive mothers to infant is estimated to be around $80-90 \%$ [5]. More than $85 \%$ of the infected children become chronic carriers [6] and $25 \%$ or more die from primary hepatocellular carcinoma or liver cirrhosis $[5,6]$.

The pattern of HBV transmission varies in different areas of Asia. In South East Asia vertical transmission is the main route of infection ( $\mathrm{HBeAg}$ is positive in $40-50 \%$ of $\mathrm{HBsAg}$ carrier mothers) but in the Middle East with fairly low rate of $\mathrm{HBeAg}$, horizontal transmission between siblings is assumed to be the main route of transmission $[7 ; 8]$.

Prevalence of HBsAg in Iran is about 3\%[9] and the rate of $\mathrm{HBeAg}$ positivity in $\mathrm{HBsAg}$ carrier mothers was shown to be about $9.7 \%[10]$. Up to present, no data on the rate of HBV transmission from mother to child is available in Iran. Here we report the role of this route of HBV transmission in Mazandaran province, as an endemic region in Iran. 


\section{Subjects and methods}

1219 pregnant women referred to 27 hospitals in 14 cities of Mazandaran province of Iran were registered in this study from 2000 to 2001 . Paired blood samples were collected from mothers and cord blood of neonates on delivery time. Mothers were informed of the program. All serum samples were stored at $-20^{\circ} \mathrm{C}$ until used.

\section{Serological tests}

All maternal sera were tested for HBsAg using ELISA (Biotest , HBsAg kit- Deutsch). The HBsAg negative samples were also tested for anti$\mathrm{HBc}$ (Behring- Enzygnost anti-HBc monoclonal kit- Germany). Serum sample from mothers who were negative for $\mathrm{HBsAg}$ and anti-HBc, were further tested for anti-HBs (Behring-Enzygnost anti-HBs monoclonal kit- Germany) according to manufacturer's instructions. Positive sera for HBsAg were also tested for anti-HBc and $\mathrm{HBeAg} /$ anti-HBe (Behring _Enzygnost $\mathrm{HBe} \mathrm{Ag} / \mathrm{Ab}$ monoclonal kit- Germany).

To evaluate HBV transmission from mothers to neonates, cord blood of babies born to $\mathrm{HBV}$ exposed mothers were tested for $\mathrm{HBsAg}$, anti-HBc, anti-HBs and $\mathrm{HBeAg} / \mathrm{Ab}$.

\section{PCR detection of HBV-DNA}

Sera from HBsAg positive mothers and cord blood samples were also tested for HBV-DNA by PCR. DNA was extracted from each serum using the method described by Wang (11), with some modification. Samples were amplified by PCR for 30 cycles using primers designed from $\mathrm{S}$ region (AB033559) with the following sequences:

\section{5' GATTCCTAGGACCCCTGCTCGTGTTAC} 3' (nt: 174-200)

5' AATTAGAGGACAAACGGGCAACATACC 3' (nt: 458-84)

After an initial heating at $94^{\circ} \mathrm{C}$ for $3 \mathrm{~min}$, amplification was performed for 30 cycles at denaturation $94^{\circ} \mathrm{C}$ for $1 \mathrm{~min}$, annealing $55^{\circ} \mathrm{C}$ for $1 \mathrm{~min}$ and extension $72^{\circ} \mathrm{C}$ for $1 \mathrm{~min}$. An additional step at $72^{\circ} \mathrm{C}$ for 10 min was also included in the program.

PCR products were visualized in $1.5 \%$ agarose gels following electrophoresis. A $311 \mathrm{bp}$ PCR product was an indication of a HBV DNA positive sample (Fig1).

In each of the PCR experiments, sterile water and a normal serum were used as negative controls. Sensitivity of the PCR was evaluated using positive control from VQC catalogue (S2045, PELISPY HBV-DNA-97, 3000 copies/ml, march 1999).

\section{Results}

Prevalence of hepatitis B markers (HBsAg, antiHBs and anti-HBc) in mothers and cord blood samples from their babies are presented in table 1. The rate of HBsAg, anti-HBc and anti-HBs among mothers were $2.6 \%(32 / 1219), 10.0 \%(119 / 1187)$ and $11.9 \%(127 / 1068)$ respectively. All carrier mothers were also positive for anti-HBc. Among the 25 cord blood from HBsAg-positive mothers, 5 (20\%) had detectable HBsAg.

$\mathrm{HBeAg}$ and anti-HBe antibody were detected in $12 \%(3 / 25)$ and $52 \%(13 / 25)$ of carrier mothers respectively (table 2). Simultaneous presence of $\mathrm{HBeAg} /$ anti-HBe was demonstrated in $4 \%(1 / 25)$ of carrier mothers while $32 \%(8 / 25)$ were negative for both $\mathrm{HBeAg}$ and anti-Hbe antibody. Babies born to carrier mothers having $\mathrm{HBeAg}$, anti-HBe and $\mathrm{HBeAg} / \mathrm{Ab}$ were $100 \%$ positive for each marker, while none of the cord blood samples were positive for HBV-DNA (data not shown).

The distribution of HbeAg and HBV-DNA was compared in HBsAg positive and negative mothers (table 3). HBV-DNA was detected in $12 \%(3 / 25)$ of carriers and $6.5 \%(5 / 76)$ of non carrier mothers with anti-HBc (statistically was not significant).

\section{Discussion}

The high rate of HBsAg transmission in the Asian population is supposed to be associated with maternal neonate close contact during birth or soon after $[4,8]$. The risk of HBV transmission to infants from $\mathrm{HBeAg}$ positive mothers is estimated to be $80-90 \%$, with more than $85 \%$ of the infants becoming chronic carriers[6] .

Our study indicated that $2.6 \%$ of the pregnant women were $\mathrm{HBsAg}$ positive; this is similar to our previous study (3\%) in Tehran [12]. The rate of HBsAg carriage in our study is similar to France with 2.3\% [13] and lower than Senegal, Egypt and India with $13.8 \%, 11.1 \%$ and $6.34 \%$ respectively $[4,14,15]$, higher than $1 \%$ in both Switzerland and United States [16, 17].

Maternal transmission of HBV may occur in utero, perinatally and post-natally $[18,19]$. In our study HBsAg was positive in $20 \%$ of cord blood samples (table 1) similar to Egypt[4] and India [15] where HBsAg was shown to be transmitted through cord 
Safieh Amini et. al.

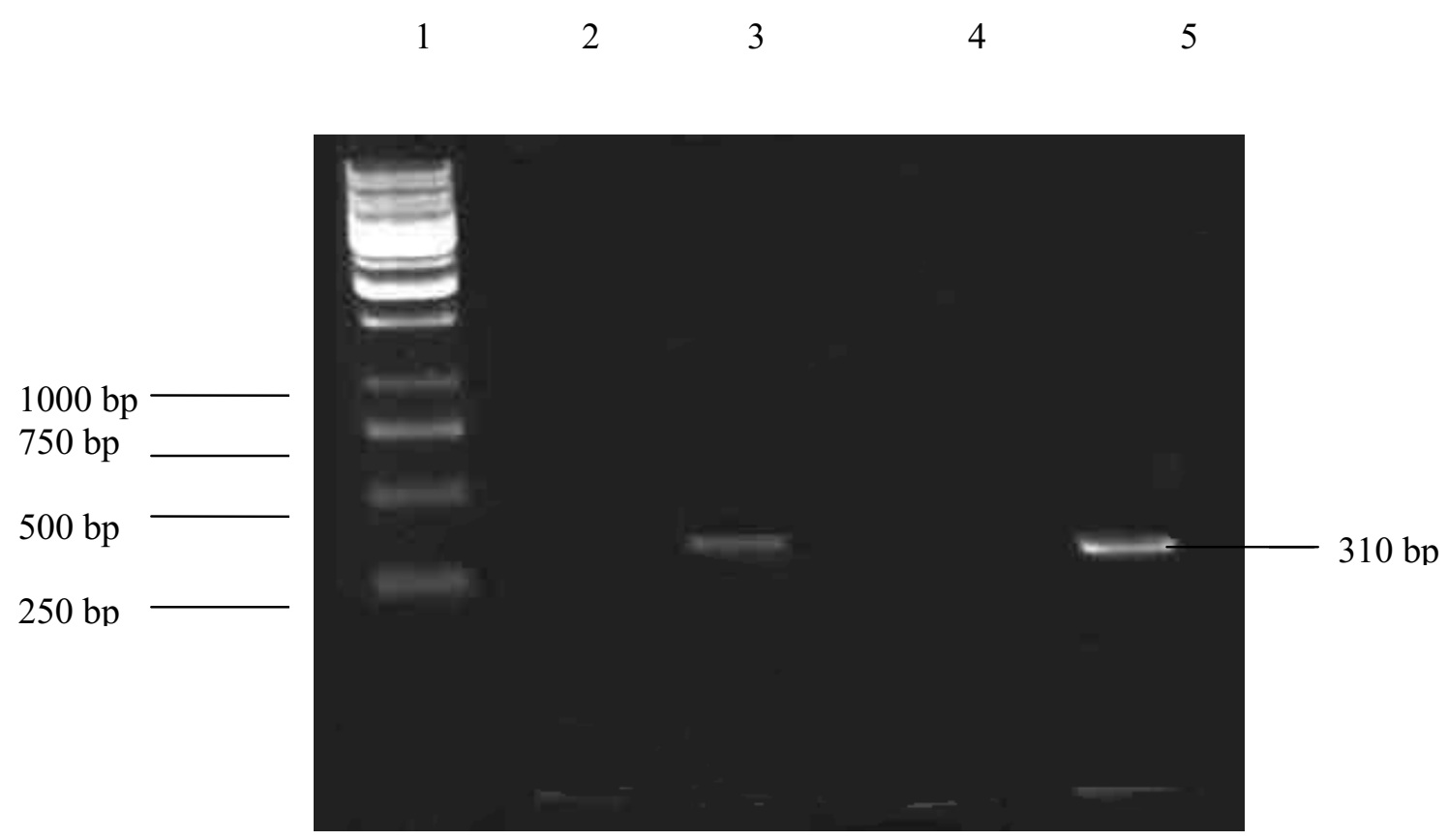

Fig 1 PCR amplification of HBV DNA. Lane1:MW Marker (1kb). Lane2: Negative control serum. Lane 3: HBV DNA positive PCR control, Lane 4: negative samples and Lane 5: HBV DNA positive PCR sample.

Table 1 Frequency of HBsAg, anti-HBc and anti-HBs in mothers and cord blood from HBV exposed mothers in Mazandaran province of Iran, 2001.

\begin{tabular}{|c|c|c|c|}
\hline \multirow{4}{*}{ Mother } & Marker & No. tested & Positive (\%) \\
\hline & HBsAg & 1219 & $32(2.6) \dagger$ \\
\cline { 2 - 4 } & Anti-HBc & 1187 & $119(10.0)$ \\
\cline { 2 - 4 } & Anti-HBs & 1068 & $127(11.9)$ \\
\cline { 2 - 4 } & Total & 1219 & $278(22.8)$ \\
\hline \multirow{3}{*}{$\begin{array}{c}\text { Cord blood samples from HBV } \\
\text { exposed mother }\end{array}$} & HBsAg & 25 & $5(20.0)$ \\
\cline { 2 - 4 } & Anti-HBc & 76 & $27(35.5)$ \\
\cline { 2 - 4 } & Anti-HBs & 46 & $28(60.9)$ \\
\cline { 2 - 4 } & Total & 147 & $60(40.8)$ \\
\hline
\end{tabular}

$\uparrow$ all mother carriers were positive for anti-HBc

Table 2 Rate of HBsAg in cords blood in relation to HBeAg/Anti-HBe status of HBsAg positive mothers, Mazandaran province of Iran 2001.

\begin{tabular}{|c|c|c|c|c|}
\hline \multirow[b]{2}{*}{ HBsAg +ve mothers } & \multicolumn{4}{|c|}{ Babies' cord blood } \\
\hline & $\begin{array}{l}\mathrm{HBeAg} \\
+\mathrm{ve} \%\end{array}$ & $\begin{array}{c}\mathrm{HBe} \\
\mathrm{Ab}+\mathrm{ve} \%\end{array}$ & $\begin{array}{c}\mathrm{HBe} \mathrm{Ag} / \mathrm{Ab} \\
+\mathrm{ve} \%\end{array}$ & $\mathrm{HBe} \mathrm{Ag} / \mathrm{Ab}-\mathrm{ve} \%$ \\
\hline HBe Ag +ve $(n=3)$ & 100 & - & - & - \\
\hline $\mathrm{HBe} A b+v e(n=13)$ & - & 7.6 & - & - \\
\hline $\begin{array}{lll}\mathrm{HBe} & \mathrm{Ag} / \mathrm{Ab} & +\mathrm{ve} \\
(\mathrm{n}=1) & & \end{array}$ & - & - & 100 & - \\
\hline $\begin{array}{lll}\begin{array}{l}\mathrm{HBe} \\
(\mathrm{n}=8)\end{array} & \mathrm{Ag} / \mathrm{Ab} & -\mathrm{ve} \\
\end{array}$ & - & - & - & 0 \\
\hline Total $(n=25)$ & 3 & 1 & 1 & 0 \\
\hline
\end{tabular}


Table 3 Proportion of HBeAg and HBV-DNA in relation with mother carriers and anti-HBc positive mothers, Mazandaran province of Iran 2001.

\begin{tabular}{|l|c|c|c|}
\hline Carriers mother & $\begin{array}{c}\text { No. } \\
\text { Tested }\end{array}$ & $\begin{array}{c}\text { HBeAg } \\
\text { Positive (\%) }\end{array}$ & $\begin{array}{c}\text { HBV-DNA } \\
\text { Positive (\%) }\end{array}$ \\
\hline HBsAg positive & 25 & $3(12.0)$ & $3(12.0)$ \\
\hline Anti-HBc positive & 76 & $1(1.3)$ & $5(6.5)$ \\
\hline P-value & 0.045 & 0.312 \\
\hline
\end{tabular}

blood in $24 \%$ and $17 \%$ of neonates respectively and is higher than the report from Senegal showing that HBsAg is passed through cord blood in $7 \%$ of cases[14]

Presence of $\mathrm{HBeAg}$ is shown to be a major indication for HBV infection. In this study $100 \%$ cord blood of neonates from $\mathrm{HBeAg}$ positive mothers were positive for this marker [table 2]. In Taiwan and Japan HBeAg was detected in 40-50\% of HBsAg carrier mothers leading to infection over $90 \%$ of their neonates [1]. In Europe and USA where there are few $\mathrm{HBeAg}$ positive mothers $(0.0$ $1 \%$ ) the rate of $\mathrm{HBV}$ transmission from mother to child is very low [17]. Considering a relatively low rate of $\mathrm{HBeAg}(8.7 \%)$ in $\mathrm{HBsAg}$ positive mothers in Babol a city in Mazandaran province of Iran [10] and the $12.5 \%$ we found in this study, it seems that vertical transmission is not the main rout of HBV infection in Mazandaran while horizontal transmission and sibling infectivity could be considered as the more likely route of $\mathrm{HBV}$ infection.

Presence of anti-HBe in patients reflects reduction of viral replication and lower infectivity and therefore less vertical transmission of HBV [1]. In our study HBsAg was present in $100 \%$ cord blood of babies born to $\mathrm{HBsAg} / \mathrm{anti}-\mathrm{HBe}$ positive mothers. This is higher than the rate of cord blood positivity reported by Yasin in Egypt (21\%)[4].

Our data also shows that $100 \%$ of cord blood samples from babies born to carrier mothers having $\mathrm{HBeAg} /$ anti-HBe markers were $\mathrm{HBsAg}$ positive (Table 2). In contrast Yasin et al [4] found that $30 \%$ of $\mathrm{HBeAg} /$ anti-HBe positive mothers could transmit HBV infection to their neonates. Probably, balance between $\mathrm{HBeAg}$ and anti-HBe should be considered for different results in these studies, if the percentage of $\mathrm{HBeAg}$ is more than anti-HBe, chance of HBV infection is higher and vice versa. In our study the rate of anti-HBe was higher than $\mathrm{HBeAg}$ in mothers ( $52 \%$ vs $12 \%$ ), showing a lower risk of vertical transmission in Mazandarn province. Similar to a report from
Thailand [20], our study indicated that none of cord blood of babies born to $\mathrm{HBeAg} / \mathrm{anti}-\mathrm{HBe}$ negative mothers was positive for HBsAg (table 2). In contrast, Lee and his colleagues in Hong Kong [21] showed a rate of $42 \% \mathrm{HBsAg}$ in neonates' cord blood from $\mathrm{HBeAg}$ negative mothers.

Alexander and Eddleston [22] believe that sometimes virus is transmitted through cord blood but maternal anti-HBc inhibits viral replication and antigen presentation. Chang et al [23] found that none of the 85 infants with a high titer of maternal anti-HBc $\left(>10^{5.42}\right)$ became HBs Ag carriers, while $7 \%$ of the 61 infants with maternal anti-HBc titer between $10^{5.12}-10^{5.42}$, and $11 \%$ of the 46 infants with low titer maternal anti-HBc $\left(<10^{5.12}\right)$ became HBsAg carriers. So they suggest a positive role of anti-HBc in the modulation of mother-to-infant transmission of HBV. A high maternal anti-HBc level in serum may be a negative predictor of immunoprophylaxis failure in high risk infants. In our study all carrier mothers were also anti-HBc positive and DNA was not detected in cord blood samples by PCR even in HBsAg positive cases (Table 3). This may be indicative of the role of maternal anti-HBc in inhibition of viral replication in cord blood [24].

In some carriers in spite of the presence of virus, HBsAg can not be detected in the serum. In these cases detection of HBV-DNA is a more sensitive method for evaluation of HBV infection $(25 ; 26)$. Our study showed detection of HBV-DNA in $6.5 \%$ of HBsAg negative mothers who had anti-HBc (Table 3). This rate was about $4.5 \%$ in Taiwan [11] and $24 \%$ in India [27]. These data emphasized that HBsAg can not be considered as the only marker of HBV infection and probably in such cases detection of nucleic acid is a more reliable parameter.

In conclusion, our results indicate that maternal HBV transmission is not the main route of infection in Mazandaran province and transmission occurs more likely later in infancy and childhood. 
So HBV infection can be prevented by the use of Hepatitis B vaccine as part of EPI programs.

\section{Acknowledgments}

This project was granted by Pasteur Institute of Iran. We thank our colleagues Mrs. S. Lamian and Mr. M. Norouzizadeh for their technical assistance in performing serological tests on study samples. We also thank our colleagues specially Mr. Imani and his colleagues in Pasteur Institute of Iran in Amol (Mazandaran) for sampling and data collection in hospitals of Mazandaran province. Our special thanks to Dr SR. Naddaf for reviewing the manuscript and valuable discussion during this study.

\section{References}

1 Ghendon Y.; 1987; Perinatal transmission of hepatitis B virus in high-incidence countries. J Virol Methods, Aug; 17(1-2):69-79.

2 Chen DS.; 2000; Public health measures to control hepatitis B virus infection in the developing countries of the Asia-Pacific region. J Gastroenterol Hepatol, May; 15 Suppl: E7-10.

3 Toukan AU, Sharaiha ZK, bu-el-Rub OA, Hmoud MK, Dahbour SS, bu-Hassan H, et al ; 1990 ; The epidemiology of hepatitis B virus among family members in the Middle East. Am J Epidemiol, Aug; 132(2):220-32.

4 Ghaffar YA, elSobky MK, Raouf AA, Dorgham LS. ; 1989; Mother-to-child transmission of hepatitis B virus in a semirural population in Egypt. J Trop Med Hyg, Feb; 92(1):20-6.

5 Mahoney FJ. ; 1999; Update on diagnosis, management, and prevention of hepatitis $\mathrm{B}$ virus infection. Clin Microbiol Rev, Apr; 12(2):351-66.

6 Snydman DR.; 1985; Hepatitis in pregnancy. N Engl J Med, Nov 28; 313(22):1398-401.

7 Beasley RP, Hwang LY. ; 1983; Postnatal infectivity of hepatitis B surface antigen-carrier mothers. J Infect Dis, Feb; 147(2):185-90.

8 Stevens CE, Beasley RP, Tsui J, Lee WC. ; 1975; Vertical transmission of hepatitis B antigen in Taiwan. N Engl J Med, Apr 10; 292(15):771-4.

9 Amini S, Mahmoodi MF, Andalibi S, Solati AA. ; 1993; Seroepidemiology of hepatitis B, delta and human immunodeficiency virus infections in Hamadan province, Iran: a population based study. J Trop Med Hyg, Oct; 96(5):277-87.

10 Hassanjani Roshan M.R. ZpY. ; 2002; Efficacy of HBIG and vaccine in infants of HBsAg positive carrier mothers. Archives of Iranian Medicine, 2; 5:21-3.

11 Wang JT, Wang TH, Sheu JC, Shih LN, Lin JT, Chen DS. ;1991 ; Detection of hepatitis B virus DNA by polymerase chain reaction in plasma of volunteer blood donors negative for hepatitis B surface antigen. J Infect Dis, Feb; 163(2):397-9.

12 Amini S, Mahmoodi MF AS. ; 1991; Prevalence of HBsAg carrier among pregnant women in Tehran. Hepatology, 21:6.

13 Soulie JC, Larsen M, Goudeau A, Parnet F, Dubois F, Pinon F, et al. ;1991; The perinatal transmission of the hepatitis B virus in the Paris area. Ann Pediatr (Paris), Nov; 38(9):595-601.

14 Roingeard P, Diouf A, Sankale JL, Boye C, Mboup S, Diadhiou F, et al. ;1993; Perinatal transmission of hepatitis B virus in Senegal, west Africa Viral Immunol, 6(1):65-73.

15 Mittal SK, Rao S, Rastogi A, Aggarwal V, Kumari S. ;1996 ; Hepatitis B potential of perinatal transmission in India. Trop Gastroenterol, Jul; 17(3):190-2.

16 Bart PA, Jacquier P, Zuber PL, Lavanchy D, Frei PC. ; 1996; Seroprevalence of HBV (anti-HBc, HBsAg and anti-HBs) and HDV infections among 9006 women at delivery. Liver, Apr; 16(2):110-6.

17 Stevens CE, Toy PT, Tong MJ, Taylor PE, Vyas GN, Nair PV, et al. ;1985 ; Perinatal hepatitis B virus transmission in the United States. Prevention by passiveactive immunization. JAMA, Mar 22;253(12):1740-5.

18 Lee SD, Lo KJ, Tsai YT, Wu JC, Wu TC, Yang ZL, et al. ;1988 ; Role of caesarean section in prevention of mother-infant transmission of hepatitis B virus. Lancet, Oct 8;2(8615):833-4.

19 Lin HH, Lee TY, Chen DS, Sung JL, Ohto H, Etoh T, et al. ;1987 ; Transplacental leakage of HBeAg-positive maternal blood as the most likely route in causing intrauterine infection with hepatitis B virus. J Pediatr, Dec; 111(6 Pt 1):877-81.

20 Suvatte V, Assateerawatts A.; 1980; Vertical transmission of the hepatitis B surface antigen in Thailand. Southeast Asian J Trop Med Public Health, Dec;11(4):582-7.

21 Lee AK, Ip HM, Wong VC. ; 1978; Mechanisms of maternal-fetal transmission of hepatitis B virus. J Infect Dis, Nov; 138(5):668-71.

22 Alexander GJ, Eddleston AL.; 1986; Does maternal antibody to core antigen prevent recognition of transplacental transmission of hepatitis-B-virus infection? Lancet, Feb 8; 1(8476):296-7.

23 Chang MH, Hsu HY, Huang LM, Lee PI, Lin HH, Lee CY. ; 1996; The role of transplacental hepatitis B core antibody in the mother-to-infant transmission of hepatitis B virus. J Hepatol, Jun; 24(6):6749.

24 Tanaka J.; 2002; Hepatitis B epidemiology in Latin America. Vaccine, Feb 18;18 Suppl 1:S17-S19.

25 Thiers V, Nakajima E, Kremsdorf D, Mack D, Schellekens H, Driss F, et al. ;1988 ; Transmission of hepatitis B from hepatitis-B-seronegative subjects. Lancet, Dec 3;2(8623):1273-6.

26 Wang Z, Zhang J, Yang H, Li X, Wen S, Guo Y, et al.; 2003; Quantitative analysis of HBV DNA level and $\mathrm{HBeAg}$ titer in hepatitis B surface antigen positive mothers and their babies: $\mathrm{HBeAg}$ passage through the placenta and the rate of decay in babies. J Med Virol, Nov; 71(3):360-6.

27 Nandi J, Banerjee K.; 1992; Detection of hepatitis B virus DNA in donor blood by the polymerase chain reaction. Natl Med J India, Jan; 5(1):5-7. 